\title{
Pivotal role of sea ice sediments in the seasonal development of near-shore Arctic fast ice biota
}

\author{
Rolf R. Gradinger*, Mette R. Kaufman, Bodil A. Bluhm \\ Institute of Marine Science, University of Alaska Fairbanks, Fairbanks, Alaska 99775-7220, USA
}

\begin{abstract}
The impact of sea ice sediments on the seasonal development of sea ice biota was assessed in Alaskan nearshore fast ice. Ice, water, and seafloor sediment were sampled in spring 2002 and 2003 at 2 locations. Light in the sediment-loaded sea ice location (total particle load $=106 \mathrm{~g}$ dry mass, $\mathrm{DM}, \mathrm{m}^{-2}$ ) was reduced by more than $99 \%$ compared to the clean ice location (total particle load $=6 \mathrm{~g} \mathrm{DM} \mathrm{m}^{-2}$ ). Strong bottom ice algal blooms developed in sediment-free fast ice, reaching their maximum of $330 \mu \mathrm{g} \mathrm{chl} \mathrm{a} \mathrm{l}^{-1}\left(36 \mathrm{mg} \mathrm{chl} \mathrm{a} \mathrm{m}^{-2}\right)$ in late May. Pigment levels in sediment-laden ice

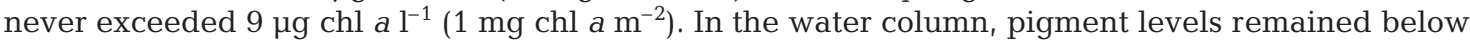

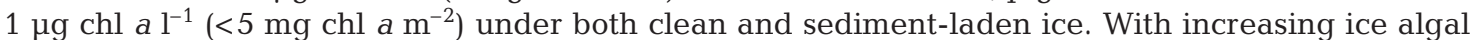
biomass, the $\delta^{13} \mathrm{C}$ ratio of sea ice particulate organic matter (POM) in clean ice increased from $-25 \%$ in February to $-16 \%$ in May, while no and little enrichment was observed in sediment-laden ice and pelagic POM, respectively. The abundance of ice metazoans in clean ice increased with progressing season from 17700 (Feb) to 276200 ind. $\mathrm{m}^{-2}$ (May), dominated by nematodes and ice-associated polychaete juveniles. In sediment-laden ice, maximum abundance was 16600 ind. $\mathrm{m}^{-2}$ (May). Abundances of meroplanktic polychaete juveniles were at least one order of magnitude below abundances in the ice, suggesting sea ice is an important feeding habitat for these young life stages. Sediment within the ice had a profound impact on sea ice biota, and delayed or inhibited the spring bloom development.
\end{abstract}

KEY WORDS: Arctic sea ice $\cdot$ Sea ice sediments $\cdot$ Ice algae $\cdot$ Ice fauna $\cdot$ Particulate organic carbon $\mathrm{POC} \cdot$ Particulate organic nitrogen $\cdot \mathrm{PON} \cdot$ Stable isotope ratio

\section{INTRODUCTION}

Light is generally accepted as the most important variable responsible for the enormous seasonality in many biological processes in polar oceans (Kirst \& Wiencke 1995, Sakshaug 2004). In sea ice, additional environmental conditions such as space availability, temperature and salinity not only reach extreme values but also vary considerably with season (Eicken 2003). These settings make the brine channel network in sea ice a habitat that is extreme, highly variable and distinctly different from any other polar marine environment (Weissenberger et al. 1992, Gradinger 2002). With the return of light in early spring, ice algal blooms form at the bottom of the ice prior to any increase in phytoplankton productivity, and ice algae are a main food source for herbivores early in the season (Horner \& Schrader 1982, Horner 1985).
Over the course of the spring, diatoms, flagellates, ciliates, nematodes, turbellarians and copepods build up considerable abundances within the bottom section of the sea ice, and amphipod and copepod crustaceans frequent the ice/water interface (e.g. Lønne \& Gulliksen 1991, Gradinger \& Bluhm 2004, Bluhm \& Gradinger 2008). In coastal fast ice locations, a plentiful assemblage of meroplankton, pelagic larvae of benthic invertebrates, augments the sea ice faunal inventory, e.g. copepod nauplii and copepodites, and larvae and juveniles of benthic polychaetes and mollusks (Carey \& Montagna 1982, Cross 1982, Kern \& Carey 1983, Grainger et al. 1985). The ice algal productivity is not only used by the ice-related fauna, but also by zooplankton and benthic feeders, specifically during periods of ice melt (e.g. Michel et al. 2002, Leventer 2003, Bluhm \& Gradinger 2008). 
The dominance of the light regime in regulating primary production in sea ice is well documented from field and laboratory experiments (e.g. Gradinger et al. 1991, Arrigo 2003, Gradinger 2009). For ice algal growth, major abiotic modifiers of available light are seasonality, ice thickness and snow cover (Maykut 1985). Only recently has sediment, incorporated within the ice, been studied with regard to its ability to modify the albedo and attenuation properties of sea ice (Light et al. 1998). Sediment occurs in concentrations above $100 \mathrm{~g} \mathrm{~m}^{-2}$ in Arctic sea ice (e.g. Nürnberg et al. 1994), and such sediment-rich patches are particularly common in the Chukchi and Beaufort Seas (Barnes et al. 1982, Osterkamp \& Gosink 1984, Eicken et al. 2005), forming so-called 'dirty ice' or 'sediment-laden ice'. Up to $50 \%$ of the entire Arctic ice cover can contain visually detectable amounts of sediment (Pfirman et al. 1989, Reimnitz et al. 1993, Nürnberg et al. 1994), which is transported across the offshore Arctic with the ice drift.

Sea ice sediments located in the top 20 to $30 \mathrm{~cm}$ of the ice alter the spectral albedo, whereas total sediment load affects light transmission (Light et al. 1998). Osterkamp and Gosink (1984) observed, for example, about 10-fold higher attenuation coefficients for sediment-laden fast ice compared to clean ice. Previous studies have demonstrated that modulation of light by snow cover is a major factor responsible for horizontal patchiness in sea ice physical and biological variables (e.g. Gosselin et al. 1986, Grossi et al. 1987, Steffens et al. 2006). In this study, we hypothesized that sea ice sediment load should also have a pronounced effect on the seasonal development of sea ice biota due to its alteration of the light regime. We expected significantly higher maximum biomass values for ice algae and higher sea ice meiofauna abundances in clean ice compared to sea ice with sediment. This hypothesis is specifically important for Arctic seas, as changing sediment loads are likely to occur in the near future as a result of increased coastal erosion and sediment suspension with decreasing sea ice regimes (Stierle and Eicken 2002).

\section{MATERIALS AND METHODS}

The fast ice along the Alaskan coastline forms in November/December and reaches a thickness of 1.5 to $1.8 \mathrm{~m}$ by April (Macdonald et al. 1999, Mahoney et al. 2007a,b). Break-up usually occurs between late June and mid-July (Mahoney et al. 2007b). Attached to the shore and anchored to the sea floor by up to 20 to $25 \mathrm{~m}$ deep keels (Macdonald 2000), the ice extends several $\mathrm{km}$ out onto the Chukchi and Beaufort shelves.
Two sites (Fig. 1) were selected during our first field phase (April 24 to 28, 2002) while the main experiment included 3 sampling periods February 12 to 17 (prebloom), April 1 to 5 (maximum ice algal bloom) and May 27 to 30 (end of bloom) of 2003. We selected 2 clean (no visible sediment incorporation) sites in 2002 for ice-core sampling to check for differences between sites. Both sites were approximately $200 \mathrm{~m}$ offshore in a water depth of 5 to $5.6 \mathrm{~m}$ and we only sampled in level, un-ridged areas to minimize spatial variability (e.g. Steffens et al. 2006). Having sampled 2 sites gave us flexibility in 2003 in finding areas of clean and sediment-laden ice. This flexibility was needed given the substantial year to year variability in the fast ice regime in this region (Mahoney et al. 2007a, b). In 2003, we sampled clean (without visible sediment load) ice at Site $1\left(71^{\circ} 20^{\prime} \mathrm{N}, 156^{\circ} 42^{\prime} \mathrm{W}\right)$, while all cores from Site 2 $\left(71^{\circ} 22^{\prime} \mathrm{N}, 156^{\circ} 24^{\prime} \mathrm{W}\right)$ exhibited substantial amounts of sediment in the top 40 to $44 \mathrm{~cm}$ of the ice cores (for example see Fig. 2).

Physical properties. At each location, snow depth was determined at 10 locations in a perimeter of $1 \mathrm{~m}$ around the site. Air, snow surface, snow/ice interface and ice temperatures were measured with a Traceable thermometer (accuracy of $0.05 \mathrm{~K}$ ). Ice cores were collected with an ice auger ( $9 \mathrm{~cm}$ diameter) and the total ice thickness was recorded from a minimum of 4 cores per site for each sampling event. Ice temperature was measured immediately after coring in 1 ice core per site in 10 to $20 \mathrm{~cm}$ intervals over the entire ice thickness. Temperature and salinity of the water column were determined with a YSI 85 sensor (YSI Inc.) at $1 \mathrm{~m}$ intervals. Freezing of the T/S sensor head due to cold air temperatures caused malfunction of the salinity readings in February and April 2003.

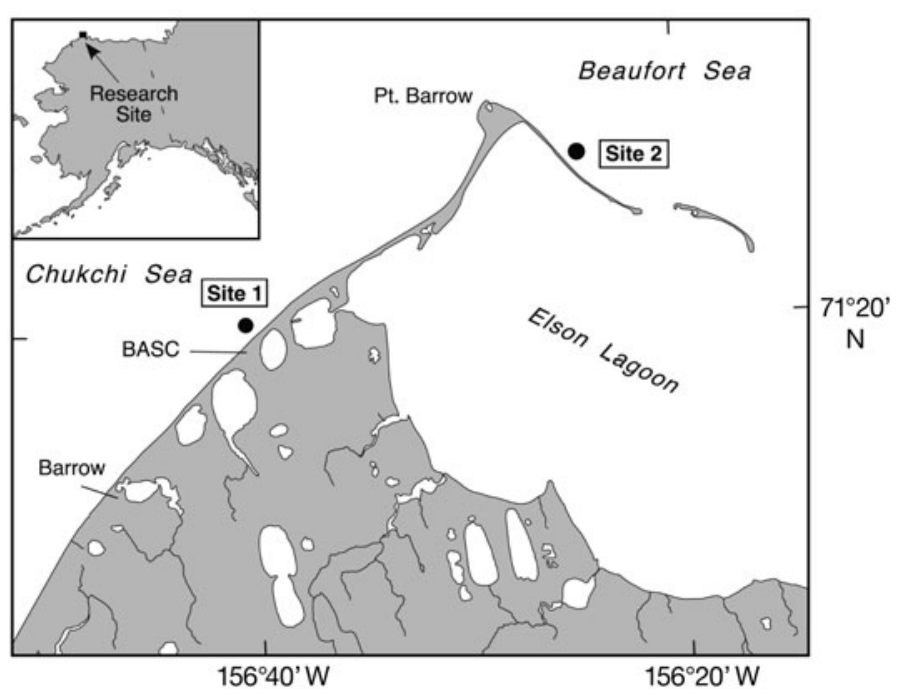

Fig. 1. Location of project sampling sites. Site 1: sediment-free ice, Site 2: sediment-loaded ice 


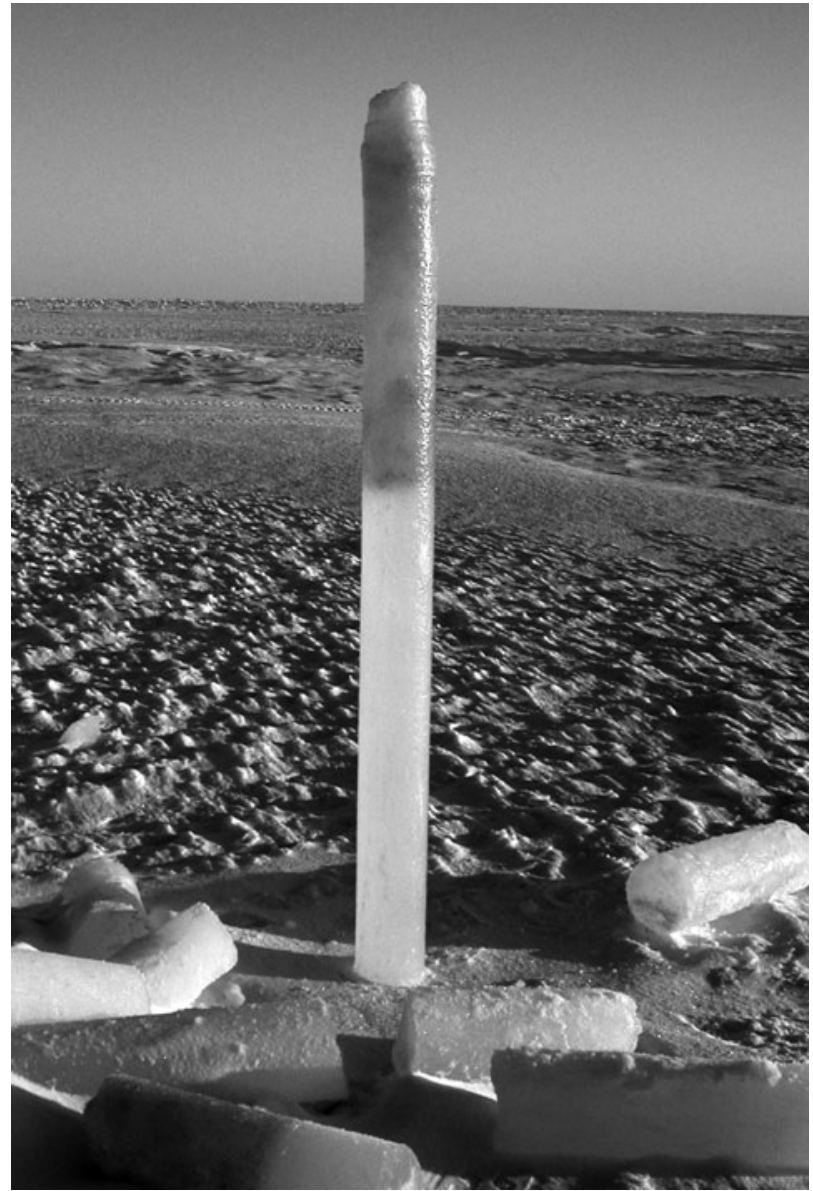

Fig. 2. Complete ice core collected at sediment-laden Site 2 on February 16, 2003. Note gray coloration due to incorporated sediments in top part of ice core, while remaining parts of the ice are nearly sediment-free. Additional ice cores (already processed) on top of fast ice

At each station and sampling date around solar noon, the PAR (photosynthetically active radiation; 400 to $700 \mathrm{~nm}$ ) photon flux density was measured with a LI-COR underwater $4 \pi$ sensor at $1 \mathrm{~m}$ intervals through a separate core hole which was covered with snow prior to readings. A $2 \pi$ sensor that remained at the ice surface provided a reference to eliminate changes due to cloud cover. Measurements were otherwise not corrected for variations in weather between sampling periods. To ensure accurate depth readings, for both light and $\mathrm{T} / \mathrm{S}$, the sensors were attached to marked fiberglass rods. In May 2003, we also determined the spectral composition of the incoming radiation on the surface of the sea ice and the downwelling radiation under the sea ice to a spectral resolution of $2 \mathrm{~nm}$ using a calibrated OceanOptics radiometer equipped with a $3 \mathrm{~m}$ long fiber-optic cable.

Biological properties. Biological samples were taken from sea ice, water column and sea floor sedi- ment in 4 replicates per site, season and variable, unless otherwise specified. Due to logistical constraints, the treatments 'sediment-laden' versus 'sediment-free' were not replicated. Based on the observed variability within the replicates of the 2002 sampling event and assuming a difference of at least a factor of 5 between clean and sediment-laden ice biological properties, an a priori power analysis (using SYSTAT 11) revealed that 3 replicates would be sufficient to detect significant differences between the sediment-free and sediment-laden locations.

Eight ice cores were taken at each site, 0.3 to $2 \mathrm{~m}$ apart from each other. Of these 8 cores, we only analyzed the bottom $10 \mathrm{~cm}$, as these generally contain the highest algal and meiofauna abundances (Horner 1985, Schünemann \& Werner 2005). In April 2003, a ninth, entire ice core from the sediment-free location was analyzed for algal pigment concentrations; the thickness of the analyzed sections was 1 to $10 \mathrm{~cm}$. In April 2003, an additional entire ice core from each location was used to determine the total seston content. Melted cores were filtered onto pre-weighted and pre-combusted GF/F filters and stored frozen until later analysis of total particulate matter by weighing the filter in the home laboratory.

For resampling the sites after the first sampling event, a handheld GPS was used to find the location, and sampling took place within a $25 \mathrm{~m}$ radius of this location.

The bottom $10 \mathrm{~cm}$ sections of Cores 1 to 4 were melted directly in the dark. After complete melt, $50 \mathrm{ml}$ sub-samples were filtered onto Whatman GF/F filters and subsequently frozen $\left(-20^{\circ} \mathrm{C}\right)$ for algal pigment analysis. Another set of $50 \mathrm{ml}$ sub-samples was filtered onto pre-combusted GF/F filters, and frozen $\left(-20^{\circ} \mathrm{C}\right)$ for later determination of total particulate organic carbon (POC), nitrogen (PON) and stable carbon and nitrogen isotope composition.

The bottom sections of Cores 5 to 8 were melted in the dark after addition of 11 of $0.2 \mu \mathrm{m}$-filtered seawater to avoid osmotic stress for the biota (Garrison \& Buck 1986). After complete melt, samples were concentrated over $20 \mu \mathrm{m}$ gauze. Metazoan ice meiofauna was sorted and counted fresh or after fixation in $4 \%$ formaldehyde using a Wild M3 dissecting microscope. Areal abundances (ind. $\mathrm{m}^{-2}$ ) were calculated by dividing the number of counted animals by the surface area of the ice corer.

Four replicate water samples were taken through the core holes from an intermediate water depth $(3 \mathrm{~m})$ with a Kemmerer water sampler. For analysis of algal pigments, total organic and inorganic matter, and stable isotope composition, 0.2 to $0.5 \mathrm{l}$ each was filtered onto GF/F filters and treated in the same way as the melted ice samples. 
Vertical plankton hauls were taken with 20 and $200 \mu \mathrm{m}$ mesh nets. Samples were sorted either live or after preservation in formaldehyde (4\% final concentration), and specimens were counted by species/taxon using a Wild M3 dissecting microscope. Areal estimates were calculated by dividing the number of animals counted by the area of the net opening.

Benthic sediment samples were collected with a benthic corer (6 cm diameter) with an attached extension deployed through an ice core hole. The top $5 \mathrm{~cm}$ of the sediment cores were collected, thoroughly mixed, and sub-samples frozen for determination of algal pigments. We did not succeed in collecting depthstratified samples within the top $5 \mathrm{~cm}$ due to difficulties with core collection and extraction at the partially extremely cold temperatures. Due to the methodological problems, we were not able to calculate areal estimates for sediment variables.

Algal pigment concentrations were determined in all 3 realms. Ice and water column samples were extracted with $7 \mathrm{ml}$ of $90 \%$ acetone for $24 \mathrm{~h}$ in the freezer (Arar \& Collins 1992). In the case of the sediment samples, $15 \mathrm{ml}$ of $90 \%$ acetone were added to approximately $1 \mathrm{~g}$ (wet weight) of sediment (Conde et al. 1999). After extraction of the sediment samples, $7 \mathrm{ml}$ of acetone were transferred into a borosilicate tube and centrifuged for $20 \mathrm{~min}$ at $1500 \mathrm{~min}^{-1}$. Pigment concentrations (chlorophyll $a$, chl $a$ and phaeophytin) were determined fluorometrically with a Turner Designs fluorometer. Phaeophorbides were determined collectively as phaeophytin. Following the pigment extraction, the sediment was dried at $60^{\circ} \mathrm{C}$ for $24 \mathrm{~h}$, and weighed. Chl a concentrations in sediment are therefore presented per $g$ dry weight sediment. Our chl a estimates are unlikely to be strongly influenced by the presence of chl $b$, as ice algal communities are typically dominated by diatoms (Gradinger 2002). Thus we assume that the effect of underestimating chl $a$ and overestimating phaeophorbides did not have a substantial impact on our data (<5\%, Arar \& Collins 1992).

Filters for stable isotope analysis were dried in a drying oven at $65^{\circ} \mathrm{C}$ for 1 to $2 \mathrm{~d}$. All filters were then $\mathrm{HCl}$ fumed in a vacuum chamber for $24 \mathrm{~h}$ and dried again. The filters were folded into tin cups and analyzed on ThermoFinnigan Delta mass spectrometers for their $\delta^{13} \mathrm{C}$ (analytical error: 0.05\%) and $\delta^{15} \mathrm{~N}$ (analytical error: $0.06 \%$ ) values and total POC and PON masses with carbon $\mathrm{PDB}$ and atmospheric $\mathrm{N}_{2}$ as standards.

For sea ice, we converted the volumetric algal pigment and POC estimates of melted sea ice to areal estimates using an average density for submerged first year ice $\left(0.91 \mathrm{Mg} \mathrm{m}^{-3}\right.$; Timco \& Frederking 1996) for the bottom $10 \mathrm{~cm}$ of our ice cores. For sea water data, we assumed a integration water depth of $5 \mathrm{~m}$.

\section{RESULTS}

\section{Physical properties}

Snow thickness varied between 3 and $7 \mathrm{~cm}$ within and among sampling events and stations. Due to an ice break-off on December 23, 2002, ice thickness at the clean ice site was less $(0.8 \mathrm{~m})$ than at the sedimentladen ice site $(1.2 \mathrm{~m})$ in February 2003. Ice thickness increased over time to maximum values of $1.3 \mathrm{~m}$ at the clean ice site and $1.7 \mathrm{~m}$ at the sediment-laden ice site in May 2003. The variability of ice thickness between replicate cores at each site and each sampling event was $<5 \mathrm{~cm}$.

Ice temperatures were lowest at the top of the fast ice and increased to seawater temperature at the bottom with no differences between the 2 sites (Fig. 3a,b). The coldest air and ice temperatures were encountered in February 2003, with minimum ice temperatures of $-25^{\circ} \mathrm{C}$ at the ice surface and air temperatures of $-30^{\circ} \mathrm{C}$. Ice temperatures in April 2003 ranged from $-13^{\circ} \mathrm{C}$ at the top of the ice cores to $-1.9^{\circ} \mathrm{C}$ at the bottom. In late May, ice temperatures had increased to between -0.2 and $-2^{\circ} \mathrm{C}$ at the ice surface. The temperature profiles in the water column (not shown) exhibited neither seasonal patterns nor any indication of vertical stratification: values ranged between -1.4 and $-2^{\circ} \mathrm{C}$. Water column salinity in May varied between 30.6 and 31.9.

The incident PAR increased with season at Sites 1 and 2 from February ( 34 and $138 \mu \mathrm{E} \mathrm{m}^{-2} \mathrm{~s}^{-1}$ ) to April (393 and $642 \mu \mathrm{E} \mathrm{m}^{-2} \mathrm{~s}^{-1}$ ) and May (886 and $1402 \mu \mathrm{E} \mathrm{\textrm {m } ^ { - 2 }}$ $\mathrm{s}^{-1}$ ). The higher values at Site 2 are due to differences in the weather conditions during sampling. Relative light intensities at the ice/water interface under sediment-laden sea ice were 2 orders of magnitude below those under sediment-free ice, and never exceeded an absolute value of $0.4 \mu \mathrm{E} \mathrm{m}^{-2} \mathrm{~s}^{-1}$ (Fig. 3c,d). At the clean ice Site 1, absolute irradiance increased with time, but the relative irradiance levels in the ice/water interface region decreased from February to April and remained low in May. Distinct differences were evident in the spectral light composition between sediment-laden and sediment-free sea ice (Fig. 3e,f). At the sedimentfree site, attenuation was highest in the blue and red wave bands, where chlorophyll has its absorbance maxima. In contrast, the spectral composition at the sediment-laden site did not indicate any preferential absorption in the PAR range (400 to $700 \mathrm{~nm}$ ).

The dry mass (DM) of particulate matter over the entire ice thickness was 15.3 times higher at sedimentladen ice Site $2\left(102.41 \mathrm{~g} \mathrm{DM} \mathrm{m}^{-2}\right)$ than at clean ice Site 1 (6.67 $\left.\mathrm{g} \mathrm{DM} \mathrm{m}^{-2}\right)$. The analysis of 4 replicate bottom sections revealed that approximately $0.9 \%$ of the total particle load was localized in the bottom $10 \mathrm{~cm}$ at the sediment-laden site $\left(0.9 \pm 0.1 \mathrm{~g} \mathrm{DM} \mathrm{m}^{-2}\right)$, while the 

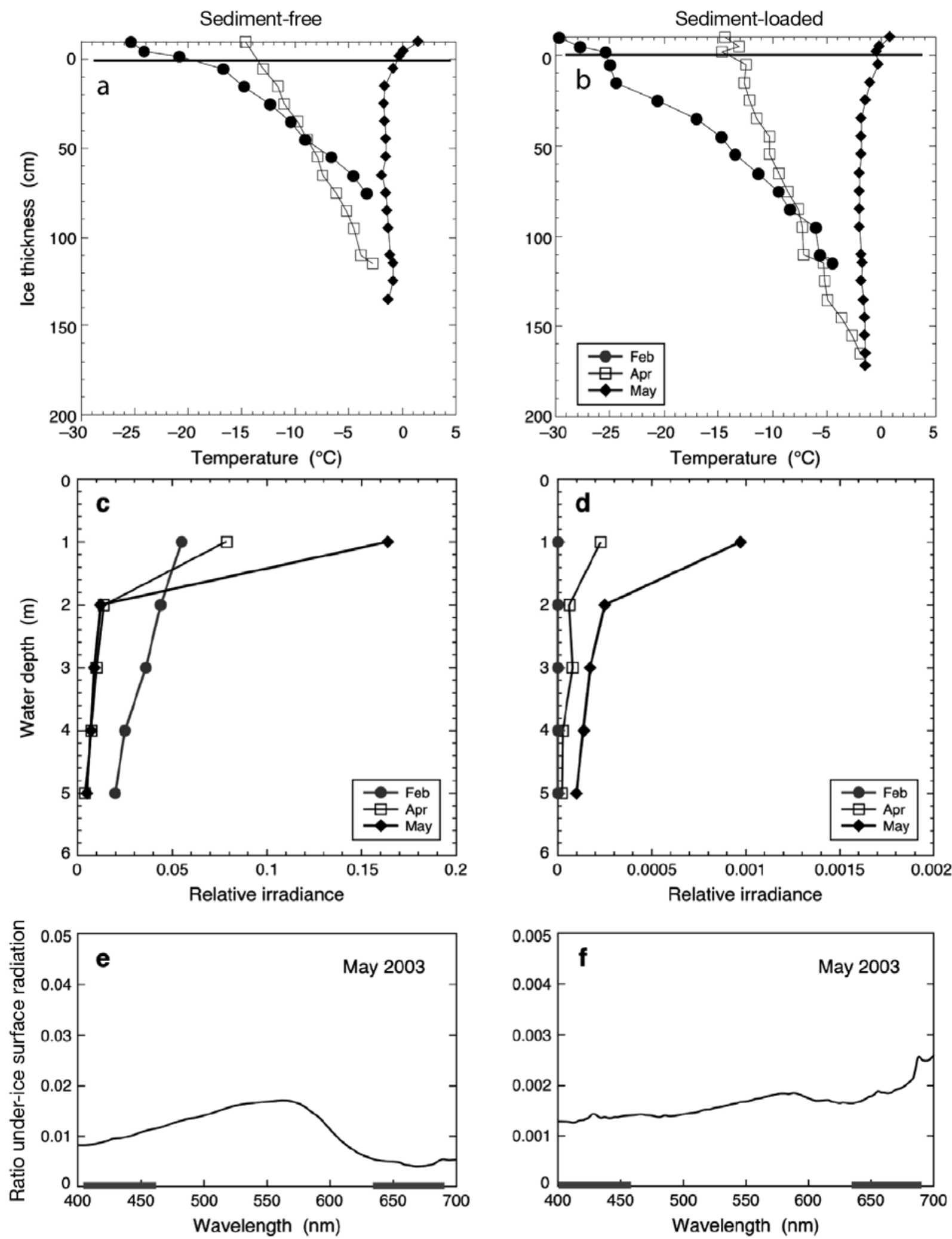

Fig. 3. Environmental variables at 2 coastal fast ice sites with no sediment (left) and high sediment load (right) in sea ice cover in 2003. (a,b) Sea ice temperatures. Horizontal line: top of ice floe; measurements above the line were made in air and snow.

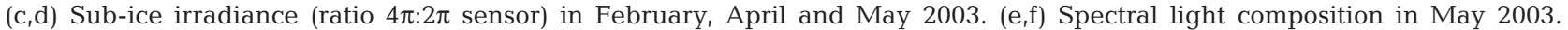
Thick gray lines along the $x$-axis: ranges of maximum chlorophyll absorption. Note differences in axis scales 
fraction at the clean ice site was considerably higher at $46.5 \%\left(3.1 \pm 0.9 \mathrm{~g} \mathrm{DM} \mathrm{m}^{-2}\right)$.

\section{Biological properties}

Our data from April 2002 revealed high ice algal pigment concentrations in clean ice at both locations with a maximum concentration of $246.8 \pm 23.5 \mu \mathrm{g} \mathrm{chl} \mathrm{a}{ }^{-1}$ at
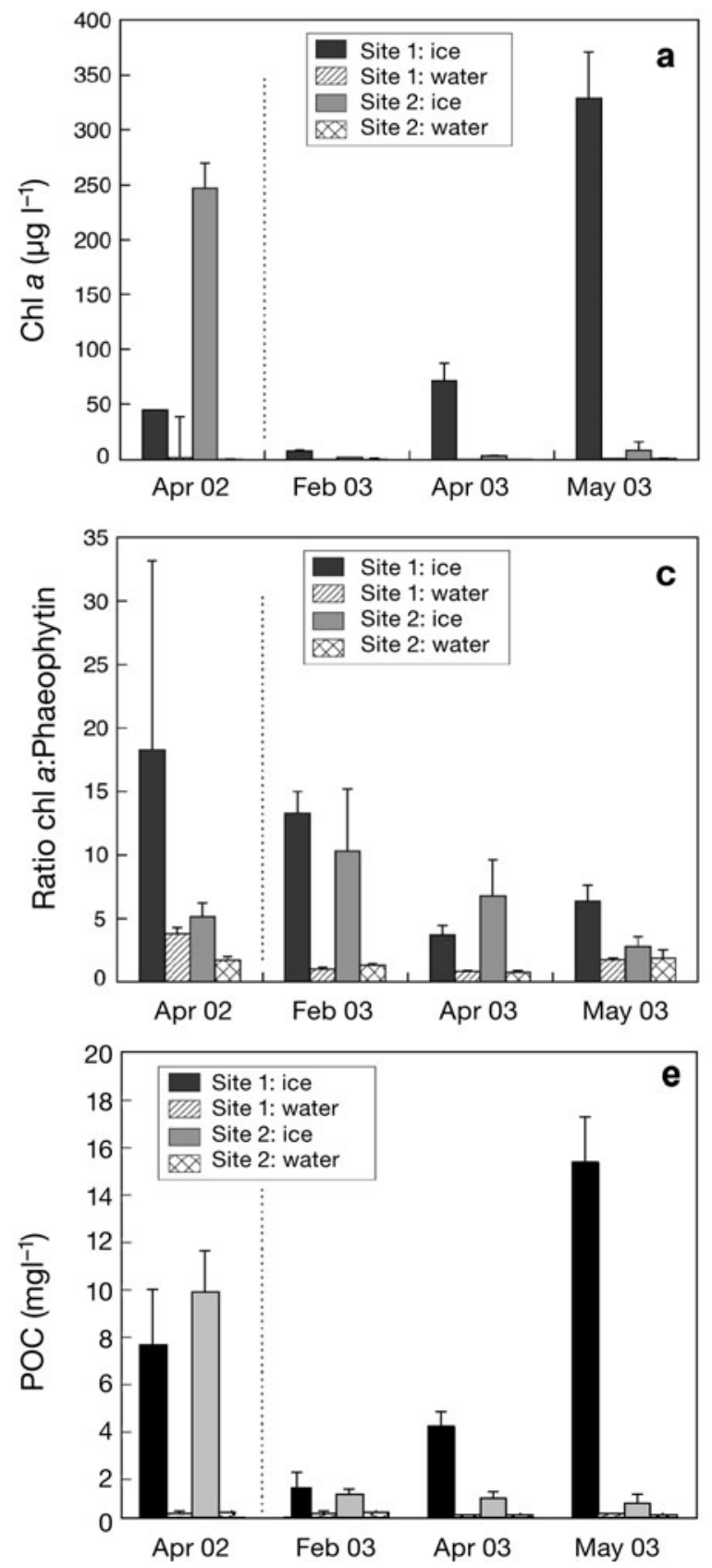

Site 2 (Fig. 4; note that Site 2 had clean ice in 2002). Analysis of algal pigment concentration at Site 1 over the entire ice thickness in April 2003 demonstrated that the bottom $10 \mathrm{~cm}$ contained $93 \%$ (7.72 $\mathrm{mg} \mathrm{chl} \mathrm{a}$ $\mathrm{m}^{-2}$ ) of the entire integrated pigment content $(8.31 \mathrm{mg}$ chl a $\mathrm{m}^{-2}$ ) (Fig. 5). Seasonal changes in ice algal biomass in the bottom $10 \mathrm{~cm}$ segments (given as mean \pm SD plus areal estimate based on the mean) were observed at both sampling locations. At the clean ice
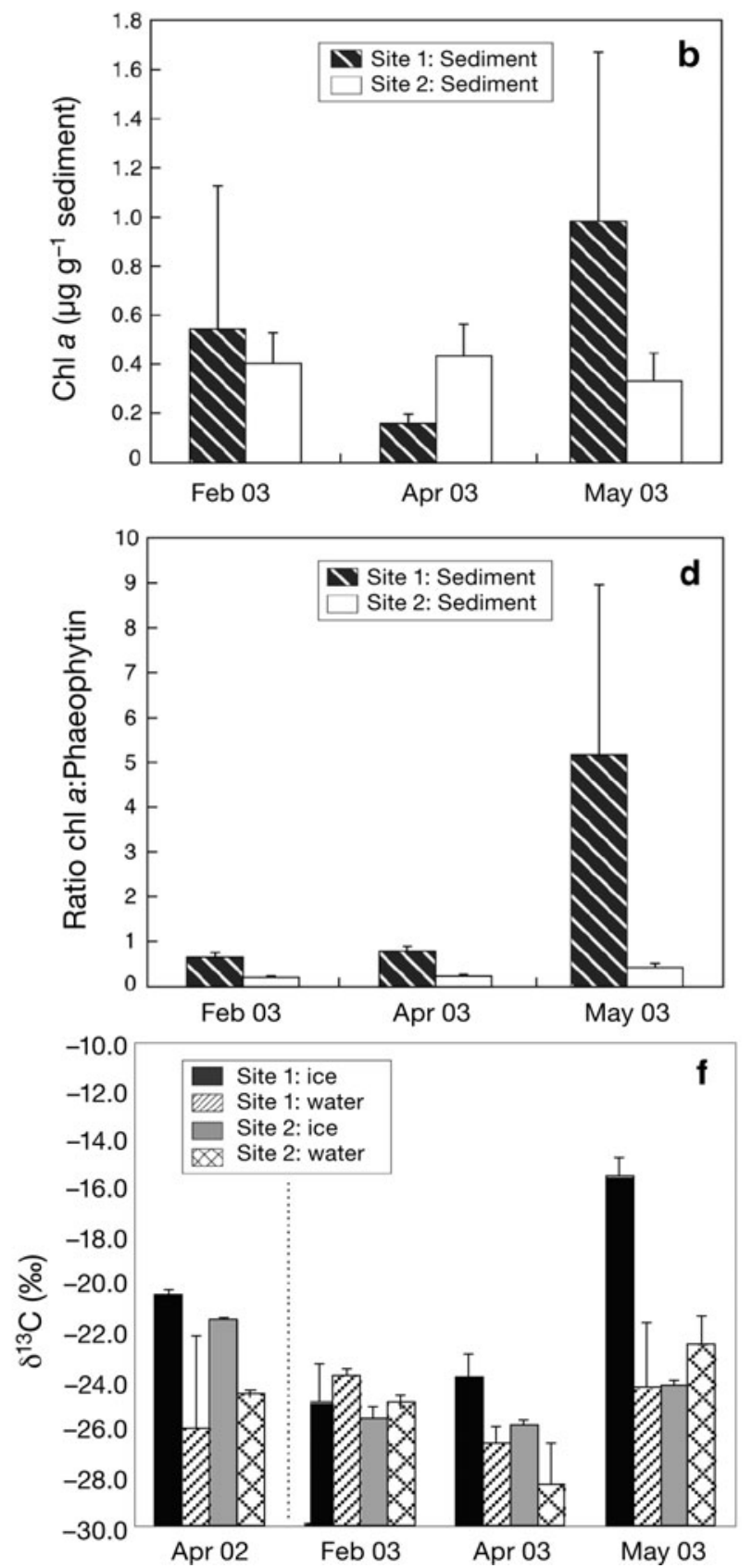

Fig. 4. Biological variables at 2 coastal fast ice sites with no sediment (Site 1) and high sediment load (Site 2) during sea ice cover in 2003. (a,b) Algal pigment concentrations and (c,d) pigment ratios (chl a:phaeophytin) in ice, water and sediment. (e,f) POC and $\delta^{13} \mathrm{C}$ in sea ice and water samples. Dotted vertical lines separate the 2002 and 2003 sampling events. Error bars represent the standard deviations 


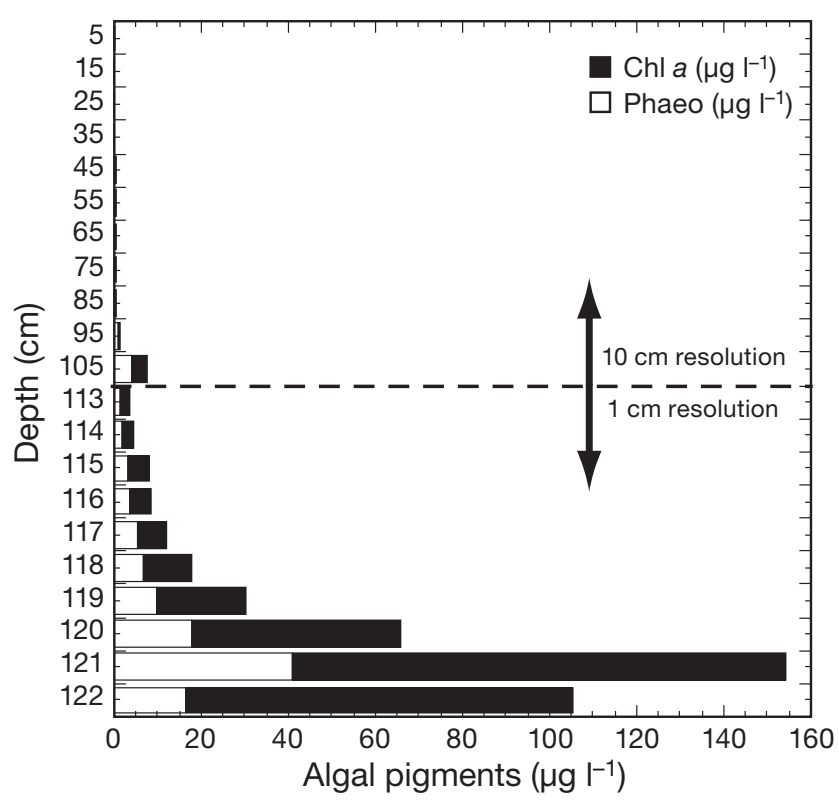

Fig. 5. Algal pigment concentration in April 2003 at Site 1. Note that the vertical resolution changes from $10 \mathrm{~cm}$ sections (top $112 \mathrm{~cm}$ ) to $1 \mathrm{~cm}$ sections in the bottom $10 \mathrm{~cm}$ of the core. Depth represents the midpoint between the upper and lower end of a section

Site 1 in 2003, algal pigment content in the bottom $10 \mathrm{~cm}$ of the sea ice increased by 2 orders of magnitude

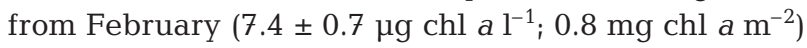

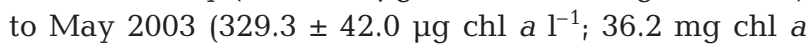
$\mathrm{m}^{-2}$ ) (Fig. 4a). In the sediment-laden sea ice (Site 2 in 2003), pigment concentration increased slightly from

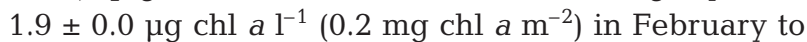
$8.3 \pm 7.0 \mu \mathrm{g} \mathrm{chl} \mathrm{a}^{-1}\left(0.9 \mathrm{mg} \mathrm{chl} \mathrm{a} \mathrm{m}^{-2}\right)$ in May 2003. The chl a:phaeophytin ratios decreased at both locations with progressing season from February (13.3 \pm 1.7 at Site 1 , and $10.3 \pm 4.9$ at Site 2$)$ to May (6.3 \pm 1.3 at Site 1 , and $2.7 \pm 0.8$ at Site 2) (Fig. 4c). Visual inspection of the ice cores immediately after coring revealed no indication of internal or surface pigment maxima in any of the cores.

Compared to sea ice algal concentrations, phyto-

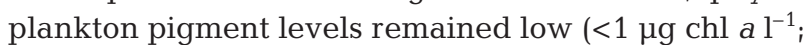
$<5 \mathrm{mg} \mathrm{chl} \mathrm{a} \mathrm{m}^{-2}$ ) throughout the 2003 study period at both locations (Fig. 4a). The chl a/phaeophytin ratios at the 2 sites were lowest in April $2003(0.7 \pm 0.1)$ and highest in late May $2003(1.8 \pm 0.6)$ with no significant site-specific differences (Fig. $4 \mathrm{c}$ ). The ratio of the mean chl a concentrations in sea ice relative to the water column increased with progressing season from 150 to 370 at the clean ice site, while it decreased from 47 to 9 at the sediment-laden ice location. Ratios of integrated algal pigments between ice and water ranged from 3.3 (February) to 16.8 (April) at Site 1, and from 0.2 (May) to 1.0 (February) at Site 2.
Mean chlorophyll concentrations in benthic sediment varied between $<0.2$ and $>1.0 \mu \mathrm{g} \mathrm{chl} \mathrm{a} \mathrm{g}^{-1}$ dry sediment throughout the sampling period at both sites. The pigment concentrations in the sediment varied considerably between replicates at the sediment-laden ice site, where the coarse sediment was difficult to sample with our corer. No seasonal trend in pigment concentrations and chl a:phaeophytin ratios was observable at the sedimentladen ice location, but they increased at the clean ice site in May when the ratio was $5.2 \pm 3.8$ (Fig. 4b,d).

The sea ice POC concentrations increased at the sediment-free location by a factor of 12 during the 2003 sampling period (Fig. 4e) from $1.3 \pm 0.6 \mathrm{mg} \mathrm{l}^{-1}(0.14 \mathrm{~g}$ $\left.\mathrm{m}^{-2}\right)$ in February to $15.2 \pm 1.9 \mathrm{mg} \mathrm{l}^{-1}\left(1.68 \mathrm{~g} \mathrm{~m}^{-2}\right)$ in May. C:N ratios in clean ice (not shown) varied between $7.4 \pm 0.1$ (April 2002) and $12.1 \pm 2.4$ (May 2003) with no clear seasonal trend. At the sediment-laden ice site, POC decreased from February $\left(1.0 \pm 0.2 \mathrm{mg} \mathrm{l}^{-1}\right.$; $\left.0.11 \mathrm{~g} \mathrm{~m}^{-2}\right)$ to May $\left(0.6 \pm 0.1 \mathrm{mg} \mathrm{l}^{-1} ; 0.06 \mathrm{~g} \mathrm{~m}^{-2}\right)$. The $\mathrm{C}: \mathrm{N}$ ratios at this site were $>10$ in both February and April 2003. No C:N ratio is available for Site 2 in May 2003. Water column POC concentrations remained below $0.2 \mathrm{mg} \mathrm{l}^{-1}\left(1.06 \mathrm{~g} \mathrm{~m}^{-2}\right)$ at both sites throughout the study period (Fig. 4e). The ratio of the integrated POC values between ice and water increased at the clean ice site from 0.2 in February to 2.6 in May. At both locations, $\mathrm{C}: \mathrm{N}$ ratios in the water column decreased over the progressing season with maximum change at the clean ice site from $18.4 \pm 11.8$ in February to $6.9 \pm 0.6$ in May.

The $\delta^{13} \mathrm{C}$ in the clean sea ice became increasingly enriched with progressing season from $-24.9 \pm 1.6 \%$ in February to $-15.5 \pm 0.8 \%$ in May (Fig. 4f). In contrast, the $\delta^{13} \mathrm{C}$ signature remained below $-25 \%$ at Site 2 in February and April, and increased slightly to $-24.2 \pm$ $0.2 \%$ in May. This relationship between $\delta{ }^{13} \mathrm{C}(\%)$ and POC $\left(\mu \mathrm{g}^{-1}\right)$ pooled for the entire data set was highly significant:

$$
\begin{gathered}
\delta^{13} \mathrm{C}=-25.964+0.0007 \times \mathrm{POC} \\
\left(\mathrm{r}^{2}=0.899, \mathrm{n}=18, \mathrm{p}<0.0001\right)
\end{gathered}
$$

At both sites, $\delta^{13} \mathrm{C}$ ratios in the water column samples were depleted in April (clean ice site: $-26.6 \pm 0.7 \%$, sediment-laden ice site: $-28.3 \pm 1.7 \%$ ) relative to February (clean ice site: $-23.8 \pm 0.3 \%$, sediment-laden ice site: $-24.9 \pm 0.3 \%$ ) and May (clean ice site: $-24.3 \pm$ $2.7 \%$, sediment-laden ice site: $-22.5 \pm 1.2 \%$ o).

The abundance of meiofauna within the sea ice followed the changes of the ice algal biomass (Fig. 6a,b). In the sediment-free ice, mean total abundance increased from 18000 ind. $\mathrm{m}^{-2}$ sea ice in February to 276000 ind. $\mathrm{m}^{-2}$ in May. In contrast, mean total abundances in the sediment-laden ice remained below 17000 ind. $\mathrm{m}^{-2}$ throughout the study period in 2003 with no seasonal trend. This cannot be attributed to site 

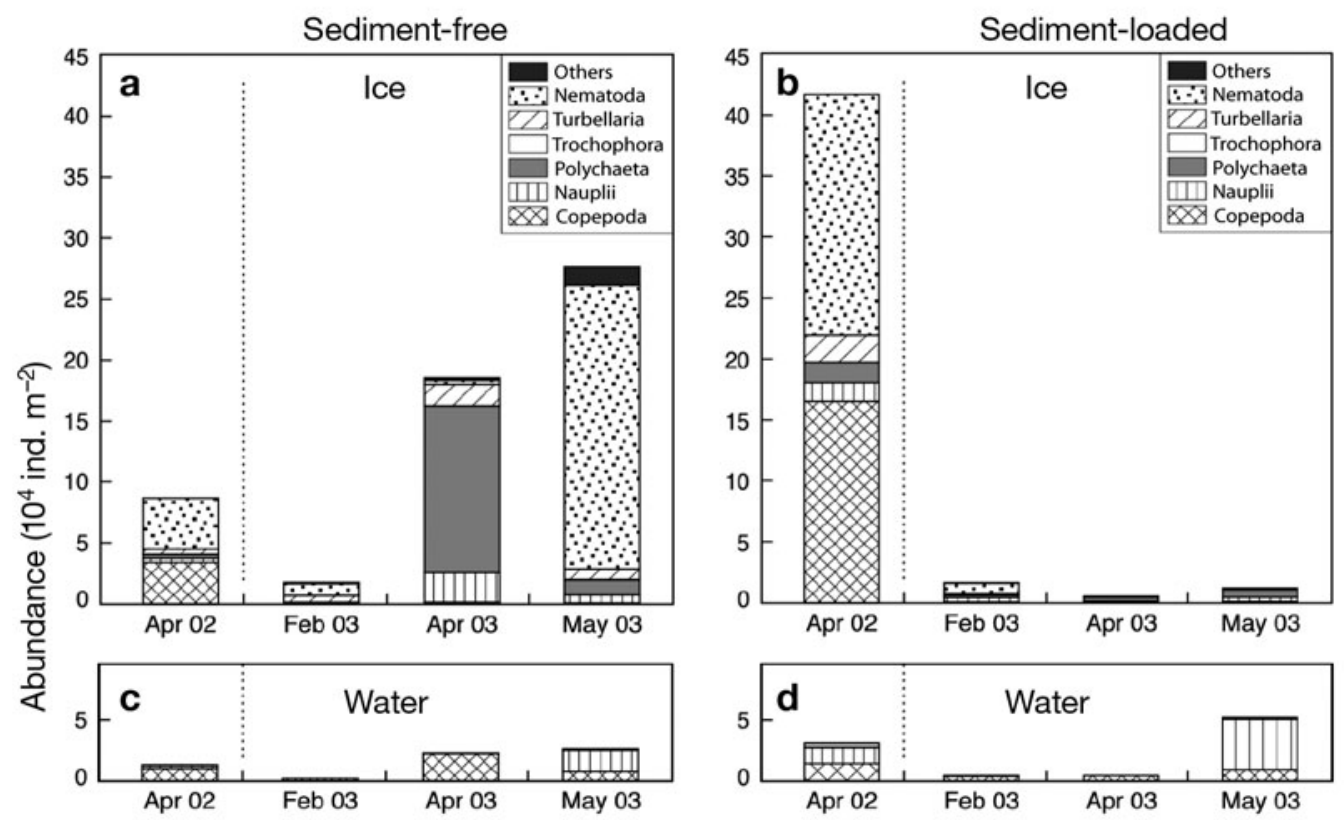

Fig. 6. (a,b) Abundance and composition of metazoans within the sea ice and $(c, d)$ in the water column beneath the sea ice in April 2002 to May 2003 in and under sediment-free ice (Site 1) and sediment-loaded ice (Site 2). Dotted vertical lines separate the 2002 and 2003 sampling events

effects, as the April 2002 mean abundance of the same location without sediment load was 416700 ind. $\mathrm{m}^{-2}$. Ice meiofauna was dominated by polychaete juveniles, nematodes, copepods (calanoid, cyclopoid and harpacticoid), copepod nauplii and turbellarians. Taxa less frequently found (listed as others, Fig. 6) included unidentified larvae, rotifers and cnidarians. Unicellular meiofauna taxa (ciliates and flagellates) occurred regularly but were not quantified. The high abundance of nematodes in May was related to active reproduction: we observed juveniles hatching out of egg cases in the laboratory while counting the samples.

Zooplankton abundances in the water column showed a seasonal increase of similar relative magnitude at both sites in 2003 (Fig. 6c,d). Values increased between February and May from 2140 ind. $\mathrm{m}^{-2}$ to 28360 ind $\mathrm{m}^{-2}$ at the clean ice Site 1 and from 4730 ind. $\mathrm{m}^{-2}$ to 56300 ind. $\mathrm{m}^{-2}$ at the sediment-laden ice Site 2. At all sampling dates, the zooplankton (Fig. 6c,d) was dominated by copepods, with nauplii starting to occur in late April (2002) and May (2003). The total abundance of polychaete juveniles in the water column was $<700$ ind. $\mathrm{m}^{-2}$ at any of the sampling events and, thus, at least one order of magnitude below sea ice values in April and May (3520 to 136600 ind. $\mathrm{m}^{-2}$ ) of the clean ice site.

Using the means for all variables of the complete sea ice data set from both sampling sites and all dates, the correlation analysis (Table 1) revealed significant relationships between various ice biota biomass and abundance variables. Chl $a$ and POC were highly significantly correlated, and the relationships between ice meiofauna abundance and chl $a$ and POC were significant at the levels of $\mathrm{p}<0.01$ and $\mathrm{p}<0.05$, respectively. The $\delta^{13} \mathrm{C}$ ratios were significantly correlated with chl $a$ and POC values.

Table 1. Correlation matrix for the entire sea ice data set based on mean values of each variable for each sampling date. Significant relationships in bold $\left({ }^{*} \mathrm{p}<0.05,{ }^{* *} \mathrm{p}<0.01,{ }^{* * *} \mathrm{p}<0.001\right)$. Light $4 \pi(\%)$ is the ratio of the PAR level at the ice-water interface compared to the surface $2 \pi$ reading. $\mathrm{C}: \mathrm{N}=$ carbon:nitrogen ratio

\begin{tabular}{|c|c|c|c|c|c|c|}
\hline & $\begin{array}{c}\text { Chl a } \\
\left(\mu \mathrm{gl}^{-1}\right)\end{array}$ & $\begin{array}{l}\text { Meiofauna abundance } \\
\text { (ind. } \mathrm{m}^{-2} \text { ) }\end{array}$ & $\begin{array}{c}\text { POC } \\
\left(\mu g \mathrm{l}^{-1}\right)\end{array}$ & $\mathrm{C}: \mathrm{N}$ & $\begin{array}{l}\text { Light } 4 \pi \\
(\%)\end{array}$ & 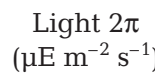 \\
\hline Meiofauna abundance (ind. $\mathrm{m}^{-2}$ ) & $0.887^{* *}$ & & & & & \\
\hline POC $\left(\mu g l^{-1}\right)$ & $0.941^{* *}$ & $0.801^{*}$ & & & & \\
\hline $\mathrm{C}: \mathrm{N}$ & -0.184 & -0.505 & -0.267 & & & \\
\hline Light $4 \pi(\%)$ & -0.035 & -0.064 & -0.048 & 0.227 & & \\
\hline 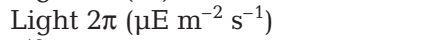 & 0.214 & 0.207 & 0.115 & -0.117 & -0.556 & \\
\hline$\delta^{13} \mathrm{C}(\% \circ)$ & $0.858^{* *}$ & 0.637 & $0.961^{* * *}$ & -0.204 & -0.039 & 0.170 \\
\hline
\end{tabular}




\section{DISCUSSION}

Our study demonstrates that sediment within the ice delays the seasonal development of the sea ice biota. In the region of high sediment load, the biological development of the spring algal bloom was retarded, and abundance of sea ice fauna was greatly reduced compared to a clean ice location. In the following, we will first discuss the biological observations at the clean ice site, and then focus on the effect of the sediment load on sea ice biological properties.

\section{Seasonal development of ice biota through a spring bloom cycle at a clean ice site}

Field and modeling efforts clearly demonstrate that increasing day length and, hence, irradiance and ice temperatures initiate the formation of the spring ice algal bloom in the bottom $10 \mathrm{~cm}$ of the sea ice (Horner \& Schrader 1982, Welch et al. 1991, Jin et al. 2006, this study).

In general, the timing and the amplitude of the ice algal spring bloom (in terms of chl a) observed at our clean ice site followed the pattern observed in previous Alaskan fast ice studies (Alexander 1974, Horner \& Schrader 1982). With progressing season, under-ice PAR intensities increased from $1.5 \mu \mathrm{mol}$ photons $\mathrm{m}^{-2}$ $\mathrm{s}^{-1}$ in February to $7.7 \mu \mathrm{mol}$ photons $\mathrm{m}^{-2} \mathrm{~s}^{-1}$ in late May. Ice algae, in general, are adapted to low-light conditions (Cota \& Smith 1991, Cota et al. 1991, Kirst \& Wiencke 1995, Mock \& Gradinger 1999), with ice algal spring bloom formation starting at PAR threshold values of about $2 \mu \mathrm{mol}$ photons $\mathrm{m}^{-2} \mathrm{~s}^{-1}$ (Horner \& Schrader 1982). Thus, light alone likely explains the low concentrations of algae in February 2003, when light intensities were just approaching the threshold. PAR values exceeded the threshold later in the season, which coincided with the observed biomass increase.

Temperature also has a major impact on ice algal growth. First, low ice temperatures, down to $-25^{\circ} \mathrm{C}$ in Barrow fast ice in February 2003, directly reduce physiological process rates. One of the very few studies on temperature effects on ice biota revealed $Q_{10}$ values of about 1 to 5 for Antarctic ice algae (Kottmeier \& Sullivan 1988). Second, low temperatures result in high brine salinities and, therefore, osmotic stress with coupled additional metabolic costs for osmoregulation for sympagic biota (Assur 1958, Gradinger 2002). Salinities $>100$, occurring at temperatures $<-6^{\circ} \mathrm{C}$, retard or completely inhibit ice algal growth (Grant \& Horner 1976, Zhang et al. 1999, Arrigo 2003). We measured such low temperatures in the upper parts of the ice cores taken in February and April (Fig. 3). The relatively warm and constant temperatures at the bottom of the sea ice (around $-1.8^{\circ} \mathrm{C}$ ) put no thermal restrictions on the formation of the bottom ice community, which contributed $93 \%$ to the total integrated algal pigment content in April 2003 at Site 1. Although we did not determine nutrient concentrations within the ice, other studies suggest that the final biomass accumulated is a function of the nutrient supply from the water column (e.g. Cota et al. 1987, Gradinger 2009).

In April 2003, algal pigment concentrations were 20fold higher than in February, which is similar to data from other areas, where biological values increased by about 10 for algal and bacterial biomass, and over 50 for primary and bacterial production (Horner 1980, Smith et al. 1988, Gradinger et al. 1991, Haecky \& Andersson 1999). The POC values exhibited the same temporal trend as the chl a concentrations, resulting in the significant correlation to chl a. By April 2003, the integrated algal biomass at Site 1 (8.3 $\mathrm{mg}$ chl a m${ }^{-2}$ ) was higher than in pack ice of the transpolar drift system in the spring (Gradinger 1999a and unpubl. data; median $=1.4 \mathrm{mg} \mathrm{chl} \mathrm{a} \mathrm{m}^{-2}$ ), but even during its maximum in May 2003 (36.2 $\mathrm{mg} \mathrm{chl} \mathrm{a} \mathrm{m}^{-2}$ ), it was lower than in other near-shore studies, where maximum values exceeded $300 \mathrm{mg} \mathrm{chl} \mathrm{a} \mathrm{m}^{-2}$ (Smith et al. 1990). By the end of May 2003, a final biomass of $15.2 \pm 1.9 \mathrm{mgC}^{-1}$ was reached within the bottom $10 \mathrm{~cm}$ of the ice. The integrated POC value of $1.7 \mathrm{~g} \mathrm{~m}^{-2}$ in May 2003 represents the net biomass accumulation over the entire spring bloom. This is less than the yearly primary production estimates for fast ice off Barrow $\left(5 \mathrm{gC} \mathrm{m}^{-2}\right.$; Alexander 1974, Horner 1984) but more than further east in the Beaufort Sea off Narwhal Island $\left(0.7 \mathrm{gC} \mathrm{m}^{-2}\right.$, Horner \& Schrader 1982).

Assuming that loss terms such as grazing or sedimentation are minor during the build up of the ice algal spring bloom (Gradinger 1999b, Nozais et al. 2001, Michel et al. 2002), the chlorophyll increase over the $103 \mathrm{~d}$ between the February and May sampling converts into an algal growth rate of $0.037 \mathrm{~d}^{-1}$, or an algal doubling time of $18.8 \mathrm{~d}$. This estimate is in accordance with data from other field studies on Arctic (Gradinger et al. 1991: $10 \mathrm{~d}$ ) and Antarctic pack ice (Grossi et al. 1987: 10 d) under natural snow-cover conditions. Spring ice algal growth rates at other Arctic locations like Resolute are significantly higher, as observed by Michel et al. (1996: growth rate of $0.14 \mathrm{~d}^{-1}$ between May 4 and May 14, 1992) or modeled by Lavoie et al. (2005: mean of 0.15 to $0.18 \mathrm{~d}^{-1}$ ). All rates, however, were well below the empirical potential growth rate maximum of $0.52 \mathrm{~d}^{-1}$ for a temperature of $-2^{\circ} \mathrm{C}$ (Eppley 1972), indicating ignored substantial loss terms, or, more likely, sub-optimal growth conditions (e.g. light, temperature and nutrient limitation) under in situ conditions. The latter exert substantial environmental stress on fast ice algae in our study area, as 
expressed in sub-optimal photochemical yields (Manes and Gradinger 2009). Differences between regions (e.g. Barrow versus Resolute) are likely due to differences in water column nutrient concentrations and strength of tidal currents causing regional gradients in ice algal development (e.g. Gradinger 1999a, 2009, Bluhm \& Gradinger 2008).

Sea ice algae exceeded the algal pigment concentrations of both phytoplankton and microphytobenthos, likely due to the very low light intensities under the sea ice (Horner \& Schrader 1982, Glud et al. 2002). For microphytobenthos Glud et al. (2002) estimated a minimum photon flux density (PFD) of $>4.5 \mu \mathrm{mol} \mathrm{m}^{-2} \mathrm{~s}^{-1}$ for positive net photosynthesis, which was never exceeded in our study region at $5 \mathrm{~m}$ water depth where we measured a PFD range of 0.8 (February) to $3.8 \mu \mathrm{mol}$ $\mathrm{m}^{-2} \mathrm{~s}^{-1}$ (May 2003) at Site 1. Our observations indicate that no substantial primary production occurred during our period of investigation in the plankton and benthic habitat in these nearshore Arctic waters, in agreement with Horner and Schrader (1982).

The small-scale spatial patchiness based on the variability of the chl a concentrations between the 4 replicates at each sampling date ( $\mathrm{SD} /$ mean $=9$ to $23 \%$ ) is similar to that of studies in other areas, where the small-scale patchiness was $<15 \%$ in constant environmental settings, especially regarding snow depth (Steffens et al. 2006). In contrast, larger-scale variability between stations in a geographical area can exceed $50 \%$ in the same season (Gosselin et al. 1997, Gradinger 1999a, Haecky and Andersson 1999), again related to environmental variables, in particular light availability and nutrient supply (Sullivan et al. 1985, Gosselin et al. 1986, Cota \& Horne 1989, Gradinger et al. 1991, Legendre et al. 1991). Light availability also explains the difference between the 2 sites in April 2002, as relative under-ice light levels were 1.3 times higher at the higher biomass Site $2(0.5 \%$ of surface irradiance) compared to Site $1(0.38 \%)$.

Ice algae are considered to be generally isotopically heavier than phytoplankton (Hobson et al. 1995, Naidu et al. 2000, Schubert \& Calvert 2001). Our data reflect the wide range of possible $\delta^{13} \mathrm{C}$ ratios in ice algae and sea ice POC, ranging from $-24.9 \pm 1.6 \%$ in February to $-15.5 \pm 0.8 \%$ in late May. While the February sea ice POC data were close to those of Arctic phytoplankton (Hobson et al. 1995, Schubert \& Calvert 2001, this study), the signatures became significantly enriched with increasing POC concentration (Tremblay et al. 2006 , this study). The water column $\delta^{13} \mathrm{C}$ ratios, in contrast, showed little enrichment over the time of our study (see discussion below). Consequently, sea ice POC $\delta^{13} \mathrm{C}$ ratios deviated from water column signatures over time, and the ratio of ice to water values decreased from 1.0 in February to 0.6 in May and might be used as an indicator for the temporal development of an ice algal bloom. The dynamic nature of $\delta^{13} \mathrm{C}$ sea ice signatures stresses the need to apply them with caution in food web studies (Hobson et al. 1995), as the values may vary greatly depending on the state and magnitude of the algal bloom at the time of release of this food source to the pelagic and benthic realms. This scenario is further complicated by the slow isotopic turnover in Arctic fauna (Kaufman et al. 2008).

Ice meiofauna abundance in this study was similar to that of other near-shore Arctic studies, also with respect to seasonality and relative composition (e.g. Cross 1982, Kern \& Carey 1983, Carey 1985, Grainger \& Hsiao 1990, Nozais et al. 2001, Michel et al. 2002). Copepods (mainly harpacticoids and cyclopoids) and their nauplii, turbellarians, nematodes and polychaete juveniles formed the dominant metazoan ice meiofauna taxa. Ciliates, which can numerically dominate the sea ice fauna $>20 \mu \mathrm{m}$ (Gradinger et al. 1991, Gradinger 1999b, Michel et al. 2002), were observed regularly, but were not quantified in our study.

The immigration of meroplanktic larvae of benthic copepods, polychaetes and gastropods into Arctic sea ice has been previously reported for near-shore Chukchi and Beaufort Sea waters (Carey \& Montagna 1982, Cross 1982, Kern \& Carey 1983, Nozais et al. 2001). The major immigration of larvae and juveniles of the polychaetes, in particular Scolelepis squamata (Spionidae) occurred between February (40 ind. $\mathrm{m}^{-2}$ ) and April (137 000 ind. $\mathrm{m}^{-2}$ ). Food availability, mainly ice algae, is likely the major reason for the increase in polychaete numbers, as herbivory appears to be a widespread feeding strategy for ice meiofauna in general (Grainger \& Hsiao 1990). At the time of the polychaete abundance maximum in the ice, the chl a concentration of the bottom ice community was 760 times higher than in the water column, and our data support the hypothesis that the larvae and juveniles use sea ice as a nursery ground (Carey 1992), whereas the adults inhabit the benthos. While counting the samples, we observed positive phototactic behavior of the polychaete juveniles, known from several polychaete species (e.g. McCarthy et al. 2002). This provides a mechanism for moving from the plankton into the brighter sea ice, a change from a meroplanktonic life style to one we define analogously as merosympagic. The density decrease of the ice-associated polychaete juveniles between April and late May suggests either active downward migration towards the sea floor or passive release through ice melt, as indicated by the warm ice temperatures in May. The slightly increased $\delta^{13} \mathrm{C}$ values in the seawater POC (Fig. 4f) and higher chl a: phaeophytin ratios (Fig. 4d) in the sediment in May compared to April also point towards a release of organic matter from the ice into the water column and 
sediment at the end of May, similar to that reported by Horner and Schrader (1982). On the other hand, polychaete juveniles might have out-grown the brine channel diameters by late May (Krembs et al. 2000), forcing them out of the sea ice, or they may have changed to negative phototaxis (McCarthy et al. 2002). Although we did not measure the juvenile polychaetes, we observed that the majority were larger by late spring.

Nematodes are a well-documented major component of the Arctic sea ice meiofauna. In coastal areas, several investigators noted this taxon to be especially abundant in late spring/early summer (May to June; Kern \& Carey 1983, Grainger et al. 1985, Carey 1992, this study). In agreement with our observations, Carey (1992) observed a seasonal shift in meiofauna composition from polychaetes (67\% in March) to nematodes later in the season ( $77 \%$ of total abundance in May) in fast ice in Stefansson Sound in the Beaufort Sea. In the present study, the increase in nematode abundance was caused by major reproductive activity during the May sampling. It remains unclear whether the observed association of the nematode egg cases with microalgal aggregates was an artifact introduced by sample processing, or whether it reflects a natural preference.

The abundances of sympagic nauplii, copepodites and copepods followed the temporal trend of the sympagic polychaetes with peak abundances in April 2003, which is contrary to Carey's (1992) finding of a continuous increase in copepod abundance until the end of May. The comparatively high ratio of nauplii could have resulted either from immigration of early nauplii stages into the ice or reproduction of adults within the sea ice. Examples for both strategies are documented: pelagic Antarctic copepods use coastal sea ice as a nursery ground (e.g. Kurbjeweit et al. 1993, Schnack-Schiel 2003), while Arctic and Antarctic harpacticoid sympagic copepods reproduce within the sea ice (Kern \& Carey 1983, Carey 1992).

\section{Impact of sediment load on the sympagic regime}

Considerable amounts of sediments are incorporated into fast and pack ice in the Arctic (e.g. Nürnberg et al. 1994, Eicken et al. 2005), with suspension freezing and incorporation of fine-grained sediments under turbulent conditions as the main process (Osterkamp \& Gosink 1984, Kempema et al. 1989, Reimnitz et al. 1993, Eicken et al. 1997). In the present study, the homogenous distribution of fine-grained sediment in the top $40 \mathrm{~cm}$ of the ice cores at the sediment-laden ice site (see Fig. 2 for example) suggests suspensionfreezing as the mechanism for sediment incorporation. The total particulate load at the sediment-laden ice site was within the range of data reported from visibly discolored ice in the Transpolar Drift, and the Laptev and Beaufort Seas (100 to $200 \mathrm{~g} \mathrm{~m}^{-2}$; Reimnitz et al. 1993, Nürnberg et al. 1994, Eicken et al. 1997, 2000, 2005) while 'clean ice' had an approximately 20 times lower particle load (this study, references above).

Until now, the role of sediment for sea ice had only been studied from the perspective of ice albedo and attenuation, whereas biological consequences had not been evaluated. High particulate concentrations in sediment-laden sea ice have profound impacts on the light regime experienced by the sea ice biota and phytoplankton underneath (Osterkamp \& Gosink 1984, Light et al. 1998, this study), similar to the shading effect of the snow cover (Maykut 1985, Gradinger et al. 1991). Over the period of our observations, irradiance at the sea ice/water interface at the sedimentladen ice location was reduced by 99.8 to $100 \%$ compared to the clean ice site, and PFD ranged between 0 and $0.5 \mu \mathrm{mol} \mathrm{m} \mathrm{m}^{-2} \mathrm{~s}^{-1}$. The spectral differences in the underwater light combined with out PAR data indicate that the high concentrations of ice algae not only increase the total PAR attenuation (e.g. Gradinger 2009) but also change the light spectrum, leaving a different signature compared to incorporated sediments (Maykut \& Grenfell 1975, SooHoo et al. 1987, Light et al. 1998, Mundy et al. 2007).

The reduced PAR availability in sediment-laden sea ice explains the slow algal growth relative to the sediment-free site. Even in May, the PFD was still just approaching the threshold light intensity required for ice algal growth, as determined by Mock \& Gradinger (1999), and was below levels where biomass build-up has been observed in the field (Horner \& Schrader 1982). At comparable PFD levels of 0.3 to $0.4 \mu \mathrm{mol} \mathrm{m}{ }^{-2}$ $\mathrm{s}^{-1}$, no algal growth was observed over $19 \mathrm{~d}$ in an artificially darkened Arctic pack ice area (Gradinger et al. 1991). Over the 4 mo of our observations, ice algal growth was much slower at the sediment-laden ice site (estimated doubling time of $49 \mathrm{~d}$ ) compared to the clean ice site (doubling time of $19 \mathrm{~d}$ ). We exclude factors other than sediment as a cause, as the snow load was similar at both sites and a rich algal bloom had formed at this site when it was sediment-free in April 2002. The observed reduction of PAR at the sedimentladen ice site is equivalent to the combined effect of a $50 \mathrm{~cm}$ snow load on $3 \mathrm{~m}$ thick sea ice (Maykut 1985), values that by far exceed any observed differences in these properties between Sites 1 and 2. We conclude that sediment incorporated within sea ice is a main factor controlling ice algal growth in Arctic sea ice which acts by modulating the available light intensities.

The reduction of algal growth caused by entrained sediment within sea ice has several broader implications. First, it suggests an overestimation of Arctic- 
wide ice algal biomass and primary production estimates, as most biological studies did not include material collected from sediment-laden sea ice (e.g. Gosselin et al. 1997, Gradinger 1999a, 2009, Gradinger et al. 1999). The ice algal primary production in seasonally ice-covered waters is currently estimated to contribute 4 to $26 \%$ to total primary production (Legendre et al. 1992) and even above $50 \%$ in the permanently ice-covered central Arctic (Gosselin et al. 1997). According to the results of this study, these estimates need to be corrected downward. Based on the observed biomass accumulation in terms of POC, net production in sediment-laden sea ice was reduced to $4 \%$ of the clean ice values. Assuming that $40 \%$ of the sea ice in the Arctic may be sediment-laden (Pfirman et al. 1989, Reimnitz et al. 1993, Nürnberg et al. 1994, Tucker et al. 1999), the impact of sediment-laden ice would lead to a reduction of the estimates of total annual sea ice primary production by $38 \%$. Considerable regional differences in the sediment load and consequently their biological impact need to be considered with highest incorporation rates in shallow shelf seas like the Chukchi Sea ( $50 \%$ of ice contained visible sediment) and lower concentrations ( 0 to $35 \%$ ) in the central Arctic (Tucker et al. 1999). The interannual variation in sediment incorporation (Tucker et al. 1999) will contribute to the interannual variability of primary productivity in Arctic seas in addition to other oceanographical variables (Michel et al. 2006). Global climate change might further enhance the sea ice sediment load and its transport in the Arctic by increasing the frequency and strength of storms (Proshutinsky et al. 1999, Stierle \& Eicken 2002), and cause further reduction of ice algal productivity on regional to basin-wide scales. Both arguments warrant a further evaluation of the impact of sediments on ice biological properties on an Arctic basin-wide scale.

Also, ice meiofauna abundance differed greatly between the 2 sites in 2003. The observed positive correlations between meiofauna density and POC and pigment concentrations suggest that the ice is primarily used as a feeding ground and may be less important as a habitat per se. Both functions have previously been discussed (Carey 1985, Grainger \& Hsiao 1990, Krembs et al. 2000, Gradinger 2002, Schnack-Schiel 2003). The relevance as a food-bearing habitat is supported by the differences in absolute densities between the 2 sites in 2003: few individuals were attracted to sediment-laden ice that provided protection from potential predators, but little food. Again, we consider the location per se unlikely as a cause for these differences, as ice meiofauna concentrations were very high at Site 2 in April 2002 and zooplankton abundance in the water column was similar to that at the clean ice site.
In addition to the limited food availability in sediment-laden ice, the reduced light under the ice may have had an impact on the behavior and distribution of biota, mainly of polychaetes. McCarthy et al. (2002) reported ontogenetic changes in the phototaxis of meroplanktonic polychaete larvae. One day old larvae were positively attracted, while older larvae $(28 \mathrm{~d})$ responded negatively to light. We propose that the observed phototactic attraction of the polychaete juveniles in our study may allow them to avoid sedimentladen ice patches with low algal biomass. Attraction to the brightest spots of sea ice in early spring (February to March) prior to algal growth may select for best initial conditions for later algal growth. We do not know whether light quality (spectral composition) might provide additional clues for polychaetes during site selection. At present, we do not understand how reduced organic biomass accumulation in the ice due to sediment-laden ice impacts pelagic and benthic environments, as material released from sediment-free and sediment-loaded ice areas will be mixed and distributed in the water column. However, a further evaluation of this process seems worth consideration, as the early occurrence of the ice algal peak might be crucial for benthic and pelagic animals (Carey \& Boudrias 1987, Grebmeier \& McRoy 1989, Renaud et al. 2007, Bluhm \& Gradinger 2008).

\section{CONCLUSION}

The coastal fast ice algae accumulate considerable amounts of biomass with seasonally increasing light intensities. The ice meiofauna, composed of taxa reflecting the benthic and pelagic communities, is more abundant than the zooplankton in the water column, where algal concentrations remain low until ice melts. Sediment in sea ice plays a pivotal role in controlling these biological processes in the sea ice in that sediment-laden fast ice drastically retards the spring bloom development. The reduced light intensities cause a domino effect along the sympagic food chain by reducing the build-up of ice algal biomass, causally followed by diminished development of ice meiofauna densities. This effect, moreover, alters the cryo-pelagic-benthic coupling processes in 2 ways: the input of organic matter from the sea ice to the realms below is greatly reduced, and sediment-laden ice has lower nutritional value for merosympagic larvae and juveniles.

Over the last decade, the Arctic ice cover has been shrinking and thinning, with minimum ice coverage in the Beaufort and Chukchi Seas (Walsh 2008). While implications of changes in the duration and characteristics of the ice cover have been discussed from various perspectives (e.g. Stirling \& Derocher 1993, Gradinger 
1995, Bluhm \& Gradinger 2008), we propose that sediment effects need to be incorporated into future field studies and modeling efforts dealing with the productivity of the Arctic in general, and more specifically, with Arctic ice algae.

Acknowledgements. We thank the Barrow Arctic Science Consortium (BASC) for the excellent logistical support during our stays in Barrow. H. Eicken, P. McRoy and A. Springer (all University of Alaska Fairbanks, UAF) provided sampling equipment and S. Lee (Korea Polar Research Institute), K. Meiners (Antarctic Climate and Ecosystems, Cooperative Research Centre, Australia), and K. Wedemayer (Minerals Management Service) assisted in the field. M. Hoberg (UAF) identified the polychaete juveniles. We acknowledge the constructive suggestions of 3 external referees. This project was funded through a research grant from the Coastal Marine Institute (CMI Task Order 85242) and by the School of Fisheries and Oceans Sciences, UAF. This article contributes to the Arctic Ocean Diversity Census of Marine Life project.

\section{LITERATURE CITED}

Alexander V (1974) Primary productivity regimes of the onshore Beaufort Sea, with reference to potential roles of ice biota. In: Reed JC, Sater JR (eds) The coast and shelf of the Beaufort Sea. The Arctic Institute of North America, Arlington, VA, p 609-635

Arar EJ, Collins GB (1992) In vitro determination of chlorophyll $a$ and phaeophytin $a$ in marine and freshwater by fluorescence. US Environmental Protection Agency Cincinnati, Method 445.0

Arrigo KR (2003) Primary production in sea ice. In: Thomas DN, Dieckmann GS (eds) Sea ice: An introduction to its physics, biology, chemistry, and geology. Blackwell, Oxford, p 143-183

Assur A (1958) Composition of sea ice and its tensile strength. Natl Research Council Natl Acad Sci Pub 598:106-138

Barnes PW, Reimnitz E, Fox D (1982) Ice rafting of finegrained sediment, a sorting and transport mechanism, Beaufort Sea, Alaska. J Sediment Petrol 52:493-502

Bluhm BA, Gradinger R (2008) Regional variability in food availability for Arctic marine mammals. Ecol Appl 18: S77-S96

Carey AG (1985) Marine ice fauna: Arctic. In: Horner R (ed) Sea ice biota. CRC Press, Boca Raton, FL, p 173-190

Carey AG Jr, Boudrias MA (1987) Feeding ecology of Pseudalibrotus (=Onisimus) litoralis Krøyer (Crustacea: Amphipoda) on the Beaufort Sea inner continental shelf. Polar Biol 8:29-33

Carey AG Jr, Montagna PA (1982) Arctic sea ice faunal assemblage: first approach to description and source of the underice meiofauna. Mar Ecol Prog Ser 8:1-8

Carey AG Jr (1992) The ice fauna in the shallow southwestern Beaufort Sea, Arctic Ocean. J Mar Syst 3:225-236

Conde D, Bonilla S, Aubriot L, de Leon R, Pintos W (1999) Comparison of the areal amount of chlorophyll a of planktonic and attached microalgae in a shallow coastal lagoon. Hydrobiology 408-409:285-291

Cota GF, Horne EPW (1989) Physical control of arctic ice algal production. Mar Ecol Prog Ser 52:111-121

Cota GF, Smith REH (1991) Ecology of bottom ice algae. III. Comparitive physiology. J Mar Syst 2:297-315

Cota GF, Prinsenberg SJ, Bennett EB, Loder JW, Lewis MR,
Anning JL, Watson NHF (1987) Nutrient fluxes during extended blooms of Arctic ice algae. J Geophys Res 92: 1951-1962

> Cota GF, Legendre L, Gosselin M, Ingram RG (1991) Ecology of bottom ice algae. I. Environmental controls and variability. J Mar Syst 2:257-278

Cross WE (1982) Under-ice biota at the Pond Inlet ice edge and in adjacent fast ice areas during spring. Arctic 35: $13-27$

Eicken H (2003) From the microscopic, to the macroscopic, to the regional scale: growth, microstructure and properties of sea ice. In: Thomas DN and Dieckmann GS (eds) Sea ice: an introduction to its physics, biology, chemistry, and geology. Blackwell, Oxford, p 22-81

Eicken H, Reimnitz E, Alexandrov V, Martin T, Kassens H, Viehoff T (1997) Sea-ice processes in the Laptev Sea and their importance for sediment export. Cont Shelf Res 17: 205-233

Eicken H, Kolatschek J, Freitag J, Lindemann F, Kassens H, Dmitrenko I (2000) Identifying a major source area and constraints on entrainment for basin-scale sediment transport by Arctic sea ice. Geophys Res Lett 27:1919-1922

> Eicken H, Gradinger R, Gaylord A, Mahoney A, Rigor I, Melling $H$ (2005) Sediment transport by sea ice in the Chukchi and Beaufort Seas: increasing importance due to changing ice conditions? Deep-Sea Res II 52:3281-3302

Eppley RW (1972) Temperature and phytoplankton growth in the sea. Fish Bull 70:1063-1085

Garrison DL, Buck KR (1986) Organism losses during ice melting: a serious bias in sea ice community studies. Polar Biol 6:237-239

Glud RN, Kühl M, Wenzhöfer F, Rysgaard S (2002) Benthic diatoms of a high Arctic fjord (Young Sound, NE Greenland): importance for ecosystem primary production. Mar Ecol Prog Ser 238:15-29

Gosselin M, Legendre L, Therriault JC, Demers S, Rochet M (1986) Physical control of the horizontal patchiness of seaice microalgae. Mar Ecol Prog Ser 29:289-298

> Gosselin M, Levasseur M, Wheeler PA, Horner RA, Booth BC (1997) New measurements of phytoplankton and ice algal production in the Arctic Ocean. Deep-Sea Res 44: 1623-1644

Gradinger R (1995) Climate change and biological oceanography of the Arctic Ocean. Philos Trans R Soc Lond A 352: 277-286

> Gradinger R (1999a) Vertical fine structure of algal biomass and composition in Arctic pack ice. Mar Biol 133:745-754

Gradinger R (1999b) Integrated abundances and biomass of sympagic meiofauna from Arctic and Antarctic pack ice. Polar Biol 22:169-177

Gradinger R (2002) Sea ice microorganisms. In: Bitten G (ed) Encyclopedia of environmental microbiology. Wiley, New York, p 2833-2844

Gradinger R (2009) Sea-ice algae: major contributors to primary production and algal biomass in the Chukchi and Beaufort Seas during May/June 2002. Deep-Sea Res II 56: 1201-1212

Gradinger RR, Bluhm BA (2004) In situ observations on the distribution and behavior of amphipods and Arctic cod (Boreogadus saida) under the sea ice of the high Arctic Canadian Basin. Polar Biol 27:595-603

> Gradinger R, Spindler M, Henschel D (1991) Development of Arctic sea-ice organisms under graded snow cover. Polar Res 10:295-307

Gradinger R, Friedrich C, Spindler M (1999) Abundance, biomass and composition of the sea ice biota of the Greenland Sea pack ice. Deep-Sea Res 46:1457-1472 
Grainger EH, Hsiao SIC (1990) Trophic relationships of the sea ice meiofauna in Frobisher Bay, Arctic Canada. Polar Biol 10:283-292

Grainger EH, Mohammed AA, Lovrity JE (1985) The sea ice fauna of Frobisher Bay, Arctic Canada. Arctic 38:23-30

Grant WS, Horner RA (1976) Growth responses to salinity variation in four Arctic ice diatoms. J Phycol 12:180-185

Grebmeier JM, McRoy CP (1989) Pelagic-benthic coupling on the shelf of the northern Bering and Chukchi Seas. III Benthic food supply and carbon cycling. Mar Ecol Prog Ser 53: 79-91

Grossi SM, Kottmeier ST, Moe RL, Taylor GT, Sullivan CW (1987) Sea ice microbial communities. VI. Growth and primary production in bottom ice under graded snow cover. Mar Ecol Prog Ser 35:153-164

> Haecky P, Andersson A (1999) Primary and bacterial production in sea ice in the northern Baltic Sea. Aquat Microb Ecol 20:107-118

Hobson KA, Ambrose WG Jr, Renaud PE (1995) Sources of primary production, benthic-pelagic coupling, and trophic relationships within the Northeast Water Polynya: Insights from $\delta^{13} \mathrm{C}$ and $\delta^{15} \mathrm{~N}$ analysis. Mar Ecol Prog Ser 128:1-10

Horner R (1980) Ecology and productivity of Arctic sea ice diatoms. In: Ross R (ed) Proc 6th Symp Recent Fossil Diatoms. Koeltz, Königstein, p 359-369

Horner R (1984) Primary productivity of the western Beaufort Sea. In: Barnes PW, Schell DM, Reimnitz E (eds) The Alaskan Beaufort Sea. Academic Press, Orlando, FL, p 295-310

Horner R (1985) Sea ice biota. CRC press, Boca Raton, FL

Horner R, Schrader GC (1982) Relative contribution of ice algae, phytoplankton, and benthic microalgae to primary production in nearshore regions of the Beaufort Sea. Arctic 35:485-503

Jin M, Deal CJ, Wang J, Shin KH and others (2006) Controls of the landfast ice-ocean ecosystem offshore Barrow, Alaska. Ann Glaciol 44:63-72

Kaufman M, Gradinger R, Bluhm B, O'Brien D (2008) Using stable isotopes to assess carbon and nitrogen turnover in the Arctic sympagic amphipod Onisimus litoralis. Oecologia 158:11-22

Kempema EW, Reimnitz E, Barnes PW (1989) Sea ice sediment entrainment and rafting in the Arctic. J Sediment Petrol 59:308-317

Kern JC, Carey AG Jr (1983) The faunal assemblage inhabiting seasonal sea ice in the nearshore Arctic Ocean with emphasis on copepods. Mar Ecol Prog Ser 10:159-167

Kirst GO, Wiencke C (1995) Ecophysiology of polar algae. J Phycol 31:181-199

Kottmeier ST, Sullivan CW (1988) Sea ice microbial communities (SIMCO). 9. Effects of temperature and salinity on rates of metabolism and growth of autotrophs and heterotrophs. Polar Biol 8:293-304

Krembs C, Gradinger R, Spindler M (2000) Implications of brine channel geometry and surface area for the interaction of sympagic organisms in Arctic sea ice. J Exp Mar Biol Ecol 243:55-80

Kurbjeweit F, Gradinger R, Weissenberger J (1993) The life cycle of Stephos longipes - an example for cryopelagic coupling in the Weddell Sea (Antarctica). Mar Ecol Prog Ser 98:255-262

Lavoie D, Denman K, Michel C (2005) Modeling ice algal growth and decline in a seasonally ice-covered region of the Arctic (Resolute Passage, Canadian Archipelago). J Geophys Res 110, C11009, doi:10.1029/2005JC002922

> Legendre L, Aota M, Shirasawa K, Martineau MJ, Ishikawa M (1991) Crystallographic structure of sea ice along a salinity gradient and environmental control of microalgae in the brine cells. J Mar Syst 2:347-357

Legendre L, Ackley SF, Dieckmann GS, Gulliksen B and others (1992) Ecology of sea ice biota. 2. Global significance. Polar Biol 12:429-444

Leventer A (2003) Particulate flux from sea ice in polar waters. In: Thomas DN, Dieckmann GS (eds) Sea Ice: an introduction to its physics, biology, chemistry, and geology. Blackwell, Oxford, p 303-332

Light B, Eicken H, Maykut GA, Grenfell TC (1998) The effect of included particulates on the spectral albedo of sea ice. J Geophys Res 103:27739-27752

Lønne OJ, Gulliksen B (1991) On the distribution of sympagic macro-fauna in the seasonally ice covered Barents Sea. Polar Biol 11:457-469

Macdonald RW (2000) Arctic estuaries and ice: a positivenegative estuarine couple. In: Lewis EL (ed) The freshwater budget of the Arctic Ocean. Kluwer, Amsterdam, p 383-407

Macdonald RW, Carmack EC, McLaughlin FA, Falkner FK, Swift JH (1999) Connections among ice, runoff and atmospheric forcing in the Beaufort Gyre. Geophys Res Lett 26: 2223-2226

Mahoney A, Eicken H, Gaylord AG, Shapiro L (2007a) Alaska landfast sea ice: links with bathymetry and atmospheric circulation. J Geophys Res 112. doi:10.1029/2006JC003559

> Mahoney A, Eicken H, Shapiro L (2007b) How fast is landfast sea ice? A study of the attachment and detachment of nearshore ice at Barrow, Alaska. Cold Reg Sci Technol 47: 233-255

Manes S, Gradinger R (2009) Small scale vertical gradients of Arctic ice algal photophysiological properties. Photosynth Res 102:53-66

Maykut GA (1985) The ice environment. In: Horner R (ed) Sea ice biota. CRC Press, Boca Raton, FL, p 21-82

Maykut GA, Grenfell TC (1975) The spectral distribution of light beneath first-year sea ice in the Arctic Ocean. Limnol Oceanogr 20:554-563

> McCarthy DA, Forward RB Jr, Young CM (2002) Ontogeny of phototaxis and geotaxis during larval development of the sabellariid polychaete Phragmatopoma lapidosa. Mar Ecol Prog Ser 241:215-220

Michel C, Legendre L, Ingram RG, Gosselin M, Levasseur M (1996) Carbon budget of sea-ice algae in spring: evidence of a significant transfer to zooplankton grazers. J Geophys Res 101:18345-18360

> Michel C, Nielsen TG, Nozais C, Gosselin M (2002) Significance of sedimentation and grazing by ice micro- and meiofauna for carbon cycling in annual sea ice (northern Baffin Bay). Aquat Microb Ecol 30:57-68

Michel C, Ingram RG, Harris LR (2006) Variability in oceanographic and ecological processes in the Canadian Arctic Archipelago. Prog Oceanogr 71:379-401

Mock T, Gradinger R (1999) Determination of Arctic ice algal production with a new in situ incubation technique. Mar Ecol Prog Ser 177:15-26

> Mundy CJ, Ehn JK, Barber DG, Michel C (2007) Influence of snow cover and algae on the spectral dependence of transmitted irradiance through Arctic landfast first-year sea ice. J Geophys Res 112, C03007, doi:10.1029/2006JC003683

$>$ Naidu AS, Cooper LW, Finney BP, Macdonald RW, Alexander C, Semiletov IP (2000) Organic carbon isotope ratios $\left(\right.$ delta ${ }^{13} \mathrm{C}$ ) of Arctic Amerasian continental shelf sediments. Int J Earth Sci 89:522-532

> Nozais C, Gosselin M, Michel C, Tita G (2001) Abundance, biomass, composition and grazing impact of the sea-ice meiofauna in the North Water, northern Baffin Bay. Mar 
Ecol Prog Ser 217:235-250

Nürnberg D, Wollenburg I, Dethleff D, Eicken H and others (1994) Sediments in Arctic sea ice: Implications for entrainment, transport and release. Mar Geol 119: 185-214

Osterkamp TE, Gosink JP (1984) Observations and analyses of sediment-laden sea ice. In: Barnes PW, Schell DM, Reimnitz E (eds) The Alaskan Beaufort Sea: ecosystems and environments. Academic Press, Orlando, FL, p 73-93

Pfirman S, Gascard JC, Wollenburg I, Mudie P, Abelmann A (1989) Particle-laden Eurasian Arctic sea ice: observations from July and August 1987. Polar Res 7:59-66

Proshutinsky A, Polyakov IV, Johnson MA (1999) Climate states and variability of Arctic ice and water dynamics during 1946-1997. Polar Res 18:1-8

Reimnitz E, Barnes PW, Weber WS (1993) Particulate matter in pack ice of the Beaufort Gyre. J Glaciol 39:186-198

Renaud P, Riedel A, Michel C, Morata N, Gosselin M, Chiuchiolo A (2007) Seasonal variation in benthic community oxygen demand: a response to an ice algal bloom in the Beaufort Sea, Canadian Arctic. J Mar Syst 67:1-12

Sakshaug E (2004) Primary and secondary production in the Arctic seas. In: Stein R, Macdonald, RW (eds) The organic carbon cycle in the Arctic Ocean. Springer, New York, p 57-81

Schnack-Schiel SB (2003) The macrobiology of sea ice. In: Thomas DN, Dieckmann GS (eds) Sea ice: an introduction to its physics, biology, chemistry, and geology. Blackwell, Oxford, p 211-239

Schubert CJ, Calvert SE (2001) Nitrogen and carbon isotopic composition of marine and terrestrial organic matter in Arctic Ocean sediments: implications for nutrient utilization and organic matter composition. Deep-Sea Res 48: 789-810

Schünemann H, Werner I (2005) Seasonal variations in distribution patterns of sympagic meiofauna in Arctic pack ice. Mar Biol 146:1091-1102

Smith REH, Anning J, Clement P, Cota G (1988) Abundance and production of ice algae in Resolute Passage, Canadian Arctic. Mar Ecol Prog Ser 48:251-263

Smith REH, Clement P, Head EJ (1990) Night metabolism of recent photosynthate by sea ice algae in the high Arctic.

Editorial responsibility: Hans-Heinrich Janssen,

Oldendorf/Luhe, Germany
Mar Biol 107:255-261

SooHoo JB, Palmisano AC, Kottmeier ST, Lizotte MP, SooHoo SL, Sullivan CW (1987) Spectral light absorption and quantum yield of photosynthesis in sea ice microalgae and a bloom of Phaeocystis pouchetii from McMurdo Sound, Antarctic. Mar Ecol Prog Ser 39:175-189

Steffens M, Granskog MA, Kaartokallio H, Kuosa H, Luodekari K, Papadimitriou S, Thomas DN (2006) Spatial variation of biogeochemical properties of landfast sea ice in the Gulf of Bothnia (Baltic Sea). Ann Glaciol 44:80-87

Stierle AP, Eicken H (2002) Sedimentary inclusions in Alaskan coastal sea ice: small scale distribution, interannual variability and entrainment requirements. Arct Antarct Alp Res 34:465-476

Stirling I, Derocher AE (1993) Possible impacts of climatic warming on polar bears. Arctic 46:240-245

Sullivan CW, Palmisano AC, Kottmeier S, McGrath Grossi S, Moe R (1985) The influence of light on growth and development of the sea ice microbial community in McMurdo Sound. In: Siegfried WR, Condy PR, Laws RM (eds) Antarctic nutrient cycles and food webs. Springer, Berlin, p 78-83

Timco GW, Frederking RMW (1996) A review of sea ice density. Cold Reg Sci Technol 24:1-6

Tremblay JE, Michel C, Hobson KA, Gosselin M, Price NM (2006) Bloom dynamics in early opening waters of the Arctic Ocean. Limnol Oceanogr 51:900-912

Tucker WB III, Gow AJ, Meese DA, Bosworth HW, Reimnitz E (1999) Physical characteristics of summer sea ice across the Arctic Ocean. J Geophys Res 104:1489-1504

Walsh JE (2008) Climate of the Arctic environment. Ecol Appl 18:S3-S22

Weissenberger J, Dieckmann G, Gradinger R, Spindler M (1992) Sea ice: a cast technique to examine and analyze brine pockets and channel structure. Limnol Oceanogr 37 : 179-183

Welch HE, Bergmann MA, Siferd TD, Amarualik PS (1991) Seasonal development of ice algae near Chesterfield Inlet, N.W.T., Canada. Can J Fish Aquat Sci 48:2395-2402

Zhang Q, Gradinger R, Spindler M (1999) Experimental study on the effect of salinity on growth rates of Arctic-sea-ice algae from the Greenland Sea. Boreal Environ Res 4:1-8

Submitted: June 22, 2009; Accepted: September 16, 2009

Proofs received from author(s): November 7, 2009 